Document downloaded from:

http://hdl.handle.net/10251/78344

This paper must be cited as:

Meliá Martí, E.; Martínez García, AM. (2015). Characterization and analysis of cooperative mergers and their results. Annals of Public and Cooperative Economics. 86(3):479-504. doi:10.1111/apce.12083.

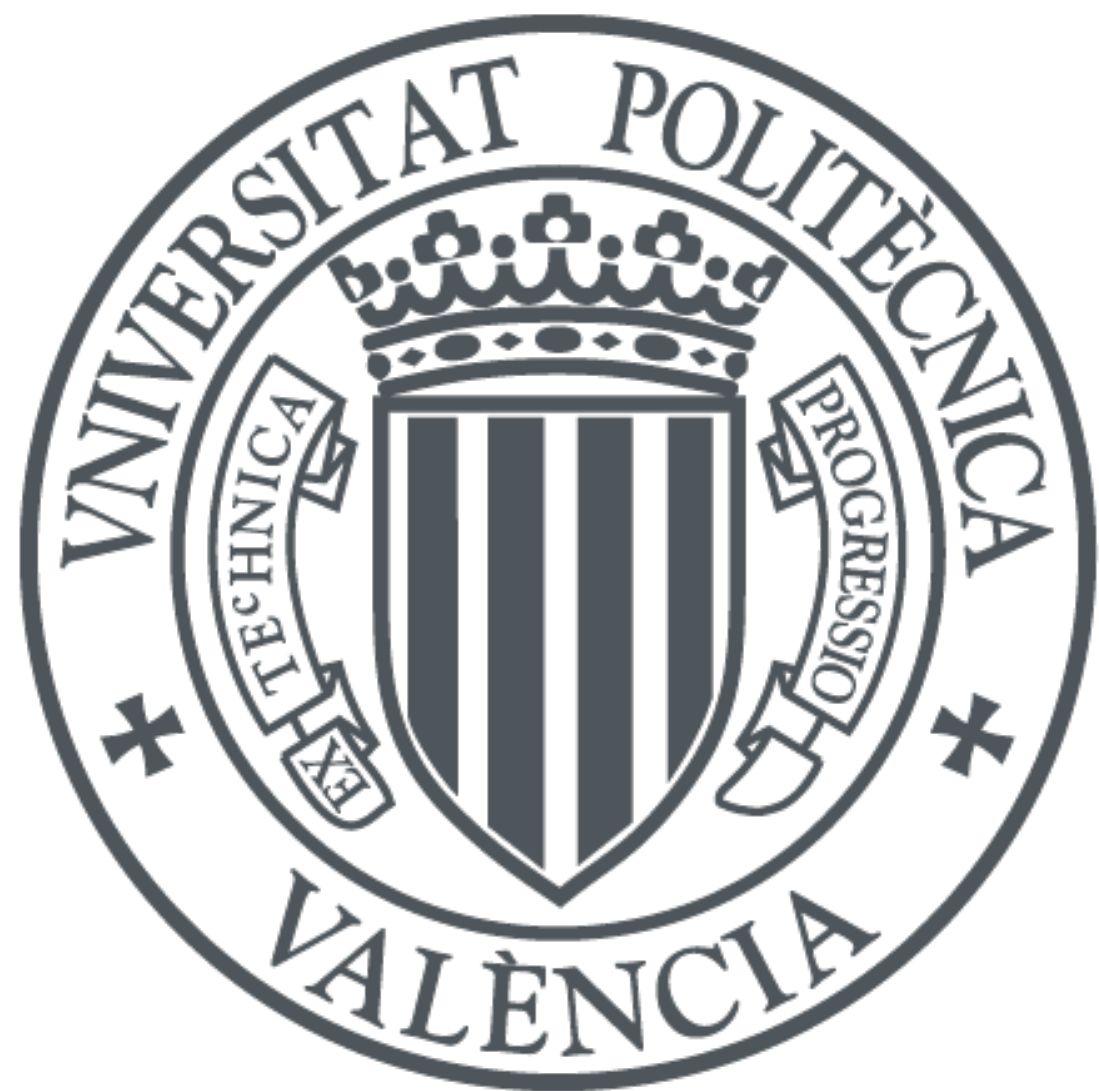

The final publication is available at

http://dx.doi.org/10.1111/apce.12083

Copyright Wiley

Additional Information

Las tablas están en otro fichero 


\title{
Characterization and analysis of cooperative mergers and their results
}

\begin{abstract}
This study characterizes the mergers and acquisitions undertaken in the Spanish agrifood sector during the period 1995-2005. First, it aims to establish the pre-merger financial characteristics of the merging cooperatives in comparison with other firms in the agrifood sector. For this, the financial situation is analyzed in the different types of merger carried out (merger by formation or merger by acquisition), and the different roles played by the cooperatives (acquiring, acquired or involved in a merger in which a new cooperative is formed). The second and final objective is to determine whether these mergers have managed to improve the economic-financial situation of the companies involved, either by increasing income and size or by reducing relative costs. For this purpose, several non parametric tests and a probit model were used. The results show that on average following a merger there were no statistically significant improvements in the economic-financial indicators studied.
\end{abstract}

\section{1.- Introduction}

Merger processes have had an impact on agrifood cooperatives in different parts of the world and the context in which these cooperatives presently operate make it likely that these processes will continue. Some markets have been liberalised, the food retail industry is increasingly dominated by large multinational firms with tremendous bargaining power, consumer markets are becoming polarised, the main trend being towards more price sensitivity and consumers are demanding more convenience products together with higher quality (Nilsson and Madsen, 2007; Bijman, 2012). This situation has been demonstrated in various European Union (EU) reports, such us the 2009 "Report on Foodstuff Prices", or the more recent "Support for Farmers Cooperatives" (2012), which points out that the need for further strengthening bargaining power will most likely lead to more (international) mergers among cooperatives, while such mergers are also induced by the need to gain economies of scope in $\mathrm{R} \& \mathrm{D}$ and branding.

In Europe, mergers have mostly been between cooperatives belonging to the same country, although there have been a few cases of cross-border unions. However, there is little empirical evidence available on merger processes, (and in the case of European cooperatives it is practically non-existent), to show whether they have achieved the expected results in different areas, such as the improvement of their economic-financial position, reducing costs, or increasing their profits and the returns paid to members. This study is structured in line with this purpose. 
Spain was chosen for its performance, since the size problem is especially apparent in its cooperatives. In fact, in spite of the effort made to re-structure Spanish cooperatives in recent years, only $1.8 \%$ of the agricultural co-ops have a turnover higher than $€ 50 \mathrm{~m}$, in $72 \%$ it is below $€ 5 \mathrm{~m}$, and $37.5 \%$ are below the $€ 1 \mathrm{~m}$ mark (OSCAE, 2013). Many studies have pointed out the atomization of Spanish agri-food cooperatives (Meliá et al., 2010, Giagnocavo and Vargas-Vasserot, 2012). The Spanish AgroAlimentary Cooperative Strategic Plan carried out by the Confederation of Cooperatives is mainly based on "structural re-dimensioning" with the aim of "promoting, facilitating and encouraging cooperatives to increase in size as a means of ensuring their viability, competitiveness and profitability" (Baamonde, 2012). The Spanish government also supports this process and passed Law 13/2013 to promote mergers among Spanish coops and other agrifood organizations in order to bring them up to date and improve their competitiveness and capacity to operate in foreign markets.

However, although a large number of authors maintain that growth is essential for the survival of the sector and for better financial performance (Russo et al., 2000, Kenkel et al., 2003 or Arcas and Hernandez-Espallardo, 2013), the relationship between size and business performance has by no means been proved. Studies on agrifood cooperatives, such as those by Mckee (2008) or Pashkova et al. (2009) have mainly concluded that there is no statistically significant relationship between profits and efficiency on one hand and cooperative size on the other. They argue that there are many other factors which affect the financial performance of the agrifood cooperatives. Similarly, Bijman (2012) points out that size is not the best factor to determine their success, and that the optimal size of a cooperative depends on the structural characteristics of the industry in which it operates and the strategy it pursues.

In Spain the second-tier cooperative is the most frequently used concentration formula (of the ten leading co-oops, five are second tier), even though mergers have taken place, especially in the last twenty years. Both forms of concentrating activities have their pros and cons. Even though in many northern European countries second-tier co-ops have become less attractive, mainly for economic efficiency and operational reasons (Bijman, 2012), there is no evidence that merging cooperatives always achieves the desired objectives or that they are the solution to the dimension problems of Spanish agrifood co-ops (Meliá \& Martínez-García, 2014). As Giagnocavo and Vargas-Vasserot point out in their Report on Spain, included in the report "Support for Farmers Cooperatives" (2012), integration and re-structuring is the formula to remedy the ills of 
atomization, but they warn that the integration strategies that have been successful in other countries cannot automatically be applied to Spain. The most appropriate methods must be researched so as to understand what functions in a complex legal, historical, social and cultural context.

\section{2.- Background and Research questions}

Numerous theoretical and empirical studies have been conducted in recent decades for the purpose of analyzing merger operations from different standpoints, and considering both the causes leading to merger processes and their effects through the use of different methodologies.

Merger theories are commonly classified into two groups: value-enhancing and non-value-enhancing theories. The former maintain that the primary aim of mergers is to maximize the firm's value (Salter and Weinhold, 1979; Seth, 1990) and assume that there will be a financial gain for shareholders in acquiring another firm (Halpern, 1983). The market for corporate control and synergy theories belong to this category.

Non-Value-enhancing theories include the agency and managerial theories and indicate that managers and shareholders have different interests and motives and that managers may act in their own interest at the expense of shareholders (Mueller, 1969; Walsh and Seward, 1990).

The efficiency theory, based on value-enhancing theories, is for many academics the dominating theory in explaining mergers. Synergy moves managers to look for economic gains in the interest of shareholders. Synergy occurs when two firms run more efficiently (through cost reductions) or effectively (through better allocation of scarce resources) than separately (Sharma and Ho, 2002). Some of these gains come from the restructuring of business activity. For example, mergers are an opportunity for making structural changes in order to reduce costs and increase efficiency (Hanan and Freeman, 1984), such as redeploying staff and closing, restructuring or replacing production plants or processes, etc.

The empirical research conducted on business merger effects can be grouped into two general areas:

- Capital market studies, which explore the effect of a merger on share prices in the form of changes in the firms' stock prices, have had varying results. Some leading studies found empirical evidence that target-firm shareholders enjoy positive returns following a takeover announcement (Jensen and Ruback, 1986; Brickley et al., 1988), 
unlike those of the acquiring firms, which showed negative returns (Langetieg, 1978; Limmack, 1991) or invariable returns (Frank et al 1991).

- Operating performance studies analyze the results of mergers using economic and financial information through the application of ratios of differing significance. However, their results vary and there is still no consensus on whether mergers contribute to an improvement in the enterprises' performance, measured in most cases through cash flow or profitability. Some of them find significant improvements in operating performance after the merger, (Healy et al., 1992; Manson et. al 2000, Rahman and Limmark, 2004). Others do not find significant post-acquisition improvements or even evidence of decline (Ravenscraft and Scherer, 1987; Clark and Ofeck, 1994; Sharma and Ho, 2002, Kumar, 2009).

In view of the corporate nature of cooperatives, and because there is no public market for cooperative equity since they do not issue publicly traded stock, our study is placed within the operating performance studies. The studies in this group focus on these backgrounds from different approaches, mainly to determine the effects of mergers on the financial position and performance of companies, and can be classified as follows:

Studies comparing a sample of merged entities to a peer group of entities that have not been merged for a particular time period encompassing the previous year and several years subsequent to the merger (Apellaniz et al. 1996; Serra et al. 2001; Kenkel et. al, 2003; Colarte and Rodriguez, 2006).

- $\quad$ Studies analyzing pre and post merger performance of the sample of merged companies against the mean ratios for the sector, through the use of industry-adjusted performance measures (Healy et al. 1992; Clark and Ofek, 1994; Sharma and Ho, 2002; Kumar, 2009). At the same time, different performance measures are used in the above studies: Cash flow measures and earnings measures, such as profitability, asset turnover, return on equity, profit margin, etc.

\subsection{Agrifood co-op mergers and their effects}

In the field of mergers of agricultural cooperatives, there is a notable lack of studies and research from an empirical perspective, with just a few international references on this topic. Richards and Manfredo, (2003(a) and (b)) found that capital constraints are the most significant factor motivating agricultural cooperatives to partake in mergers, acquisitions, joint ventures and strategic alliances, and that successful transactions tend to increase cooperative sales growth (not market power) at 
the expense of profitability. On the other hand, they describe the profile of a consolidation cooperative as efficient, minimally leveraged and less liquid than the average. Hudson and Herndon, (2000) conducted a survey of 500 agricultural cooperatives in the USA and their results showed that reducing costs through reducing duplicated personnel is the most common motivation, followed by increasing the scale (size) of the cooperatives to remain competitive and cover increasing fixed operating costs. In disagreement with the findings of Richards and Manfredo (2003), they found financial constraints are not a common motivation.

Vandeburg, J. et al. (2000) identified the most important driving forces for mergers and acquisitions in agricultural cooperatives in Indiana and Colorado. They found these to be: increased number of farms, increased costs, reduced profits, increased competition and industrialization of agriculture.

Kenkel et al. (2003) found through a study of 22 Oklahoma agricultural cooperatives that on average mergers were effective in improving profitability, efficiency and sales growth. On the other hand, Parliament and Taitt (1989) could not find any postmerger performance improvement in a study of 53 Minnesota cooperatives.

Accordingly, our research questions are:

1. What are the pre-merger financial characteristics of the merging agricultural cooperatives compared to other enterprises in the agrifood sector? This will be answered by distinguishing between the different profiles of the co-ops involved: acquiring and acquired cooperatives in acquisition mergers (in which the acquiring cooperative becomes the owner of the equity of the cooperative acquired, following which the acquiring entity is the only one that remains active), and those cooperatives involved in mergers by formation of a new entity (commonly called "mergers of equals", because neither cooperative acquires the other and a new cooperative is formed). This question is in turn further subdivided into two subsequent questions:

- 1.1. Are there significant differences between the profiles of the cooperatives analyzed: acquiring and acquired (in acquisitions) and those involved in a merger by forming a new entity?

- 1.2. What factors determine the role in an acquisition (acquiring or acquired) played by cooperatives in a merger? 
2. Do agricultural cooperative mergers result in improved efficiency (reducing costs and increasing their profits and the returns paid to members), size and financial performance?

\section{3.- Experimental design}

\subsection{Data collection, sample and analysis period}

The sample is composed of all the agrifood cooperative mergers by either acquisition or forming a new company from 1995 to $2005^{1}$. A total of 147 mergers, in which a total of $374^{2}$ cooperatives took part, were identified via consultation of all the Cooperative Registries in the different autonomous regions in Spain and their corresponding provincial offices and in certain cases the Mercantile Registers. Of these, information was available on 70 merger processes, i.e. $48.2 \%$ of the mergers, which included 147 cooperatives, a total of 312 financial statements were obtained (Table 1) to analyze the performance of each cooperative for a period of one year prior to the merger $(\mathrm{N}-1)$ to four years following the merger $(\mathrm{N}+4)$, we also needed the sector mean for each variable and year of study (1995-2005), which was based on accounting data for a total of 3,193 Spanish agri-food cooperatives, taken from the SABI database ${ }^{3}$.

To establish a sample size representative of the population, considering an accuracy degree of 1.96 , we applied a sampling error of 5\%, and a population variance of 0.25 , finite population correction (Malhotra, 2004), as the sample size obtained was more than $10 \%$ of the population. The representative sample size obtained was 62 mergers. Since our sample consists of 70 mergers (broken down in Table 6), it means that our conclusions could be generalized for the population.

Viewed by sectors, the fruit and vegetable sector led the field with the largest number of mergers $(24.3 \%)$, followed by olive oil $(17.1 \%)$, wine $(15.7 \%)$ and stockfarming (15.7\%). Only $7.1 \%$ of the mergers studied took place in the supply sector.

\subsection{Measurement of variables}

It is widely accepted that cooperatives' financial performance differs significantly from that of investor-owned firms (IOFs) and many authors question the validity of analyses based on applying financial ratios to the co-op sector and assuming a performance similar to other types of enterprise when assessing cooperative results.

1 This period excludes the crisis years, which can be considered to have started in 2006-2007, to avoid possible interferences in performance indicators.

2 Eight Agricultural Processing Companies were included because they had taken part in mergers including cooperatives and had taken on this legal form subsequent to the merger process.

${ }^{3}$ The total number of agrifood cooperatives in Spain in the period of the study was around 4,000. 
The reason is that these analyses do not consider, among other items, the particular ownership structure of cooperatives and the double role of members (i.e. users and owners). As compared to IOFs, co-ops have objectives other than simply maximizing profits (Michelsen, 1994, Baourakis, et al. 2002, James and Sykuta, 2005, Van Dijk and Klep, 2005, Soboh et al., 2009 or Sarasa et al, 2013). It is therefore advisable to evaluate their performance by a system not based exclusively on traditional financial ratios (Parliament et al, 1990, Lerman and Parliament, 1990; Pratt, 1998).

Along these lines, Soboh et al. (2009) point out that although the theoretical literature highlights the economic differences between the performance of IOFs and coops, empirical studies have not been able to follow up these theoretical approaches. In a later work, Soboh et al. (2011) attribute the reasons for this to lack of access to the appropriate information, the impossibility of considering the interests of all the members, and the difficulty of proving the different hypotheses. They further argue that the agrifood co-ops' financial ratios are difficult to interpret, since in many cases the members are paid above the market price for the products they supply to the co-op, so that returns are shared out among the members and in this way a "net zero surplus" is obtained (Moyano and Fidalgo, 2001; Kyriakopoulos et al., 2004). Studies such as those of Singh et al. (2001) or Guzmán et al. (2006) thus employ methods other than ratio analyses, such as Data Envelopment Analysis (DEA), to assess co-ops profitability and technical efficiency instead of ratio analyses.

In the present study, due to the origin of the data used, all of which was obtained from the co-ops' annual accounts, we decided to opt for a ratio-based analytical method. However, the above-mentioned restrictions as regards the use of co-ops' profit ratios made it advisable to define ratios slightly different from the normal ones, which we believe are more suited to the special conditions of these societies. The ratios we employed (see Table 2) are as follows:

- Size indicators: Turnover, Fixed Assets, or Fixed Assets/Turnover, size ratios commonly used in the literature (Kenkel et al, 2003 or Moyano and Fidalgo, 2011).

- Solvency and Liquidity Ratios: Commonly used in agribusiness literature as indicators of cooperatives' ability to pay their obligations (Baourakis et al. 2002, Kenkel et al. 2003; Hardesty and Salgia, 2004, McKee, 2008).

- Profitability Ratios: Cooperatives share out surpluses in different ways: by returning net income to patrons (in proportion to use), by receiving or paying fair prices, and by gaining access to market, supplies and services (Bijman et. al., 2012). Their 
members traditionally expect to receive their returns in the form of improved prices for their products or lower input prices, rather than from profit distribution (Lerman and Parliament, 1990). Apart from gaining access to the market, supplies and services, earnings of co-op members can therefore be considered to proceed from two sources: one from the distribution of net profits received in proportion to their use (or "patronage") of the co-op's services and another received in proportion to the value of the products the member supplies to the organization. In order to analyze these two sources of members' earnings (patronage refund and prices) two ratios were introduced:

- Return for members $=$ Net profit $($ after taxes $)+$ Supplies $/$ turnover: this reflects the capacity of the cooperative to benefit members through the payments for their products (supplies) ${ }^{4}$ and also through patronage refund relative to their turnover.

- Cash Flow for members = Net profit (after taxes) + Supplies + Depreciation / turnover: this also excludes depreciation, avoiding the effect of the merger accounting method, which in some cases involves a revaluation of assets, and as Chatterjee and Meeks (1996) showed, can distort the profits-based measurement of merger effects.

It is important to note that materials (supplies) include not only those provided by members, but also materials purchased from others. However, as a high percentage of this item is due to members' purchases, we consider the two proposed ratios are an accurate measure of the members' return, which can complement the traditional profit ratios, which are also included:

- Return on Assets (ROA): measures the ability of the cooperative to generate operating profits (which exclude financial costs and taxes) in relation to total fixed assets. This ratio can be useful for the premerger analysis, but as assets can be revalued in the merger process, it is not necessarily accurate for the postmerger analysis, as an increase or decrease in the ratio can be partly due to any change in their value.

- Operating profit ratio: measures the ability of the cooperative to generate operating profits (which exclude financial costs and taxes) in relation to turnover.

\footnotetext{
${ }^{4}$ The 70 mergers studied included 65 cases of marketing cooperative mergers and only five involved supply co-ops. These five were left out when calculating profit ratios as their members are also the organization's consumers and do not supply it with goods.
} 
- Cost efficiency ratios: Cost efficiency ratios express different costs as a percentage of revenue (supplies, staff costs, depreciation costs and financial expenses). Low cost efficiency ratios are usually desirable in order to get synergies and efficiency objectives.

Table 3 shows the characteristics of the main ratios as regards size (fixed assets), liquidity, solvency. and profitability.

\subsection{Method}

To address the first, 1.1 and the second research questions, since normality assumptions were not met, different non parametric significance tests were used:

In Research Question 1, the premerger cooperative ratios for the different roles acquiring, acquired (involved in acquisitions) and those involved in mergers by forming a new company- were compared to the mean ratios of the agrifood sector, by the Wilcoxon signed-rank test for two related samples.

In subquestion 1.1 in order to compare the merging cooperatives in the year before the merger: acquiring, acquired and cooperatives involved in a merger by forming a new company, firstly, Kruskal-Wallis one-way analysis of variance by ranks was used to compare the three independent or non related samples. Secondly, a post hoc analysis was carried out through Mann-Whitney tests for two independent samples.

To complement the results obtained in Research questions 1 and 1.1, in Research subquestion 1.2, a probit regression was performed to analyze the different profiles of acquiring and acquired cooperatives. This methodology is used to model dichotomous or binary outcome variables.

In Research Question 2, the Wilcoxon test was used to test the difference between the cooperatives and the industry before and after the merger, and between pre and post merger industry adjusted ratios. We also determined the percentage of combined firms whose ratio after the merger was greater than the ratio before the merger, both for the sector-adjusted and non adjusted ratios.

\section{4. -Results}

\section{Research Question 1: What are the financial characteristics of the merging agricultural cooperatives as compared to other enterprises in the agrifood sector?}

The financial stability of co-ops involved in mergers is a key factor in the success of the operation (Owen at al., 2011) as it has the immediate effect of increasing both their own resources and liquidity (Lago and Vaquero, 2009). As regards their premerger financial situation, some studies claim that more liquid and less leveraged 
cooperatives are more likely to merge, acquire, or form joint ventures (Richards and Manfredo, 2003).

In agreement with Richards and Manfredo (2003), our results (see Table 4) show that co-ops that have participated in a merger have no solvency or liquidity problems, being generally in a better financial situation before the process than other firms in the sector. This difference is statistically significant in all cases at a level of $1 \%$ (except in the case of immediate liquidity of the acquiring cooperatives, in which it has a significance level of $10 \%)$.

As regards size (turnover), with the exception of acquiring cooperatives, the size of the cooperatives (acquired and those involved in mergers that form a new company) is below the sector average (1\% SL and $10 \% \mathrm{SL}$, respectively). On the other hand, their investment in fixed assets is well above the sector average in all cases (1\% SL in acquired and 5\% SL in those involved in mergers by formation). This means that their fixed assets/turnover ratio is much higher than average in the sector, significantly so for both acquiring and acquired cooperatives (1\% SL and $5 \%$ SL respectively). The high level of fixed assets/turnover of entities before merging has been shown to exist in studies carried out on different sectors, such as that of Kumar Tiwari (2014) on banking. The high fixed assets/turnover ratios, higher than the mean and median in the sector, leads us to think that re-structuring assets may be one of the ways open to the co-ops studied to obtain synergies by reducing their fixed costs. Indeed, the sharing of resources as a result of a merger involves the combination and rationalization of certain operative assets of the two companies, leading to a decrease in costs due to economies of scale and scope (Haspeslagh and Jemison, 1991), one of the potential sources of synergy in merger being the lower fixed costs through better utilization of fixed assets (Schweiger and Very, 2003).

On the other hand, in all cases of co-ops that have taken part in mergers (acquiring, acquired and cooperative involved in forming a new company), they show a lower capacity to generate an operating profit from their turnover (operating profit ratio) than the sector (1\% SL).

From the results given in Table 4 three different profiles can be identified:

- Acquiring cooperatives: have a higher depreciation cost in proportion to turnover than the sector average, $10 \%$ SL. These higher depreciation costs are due to the high value of fixed assets in relation to turnover, in $64.15 \%$ of cases higher than the sector average (1\% SL). On the other hand, they have lower labour and financial costs with 
respect to turnover than the sector average (10\% and 1\% SL respectively). As regards the supplies/turnover ratio, it can be seen that $57.14 \%$ of acquiring co-ops devote a higher percentage of income to paying for production than the cooperative sector norm, although this difference is not significant.

- Acquired cooperatives: show a return for members (in both patronage dividends and in the percentage of turnover destined to buying products, including from their members, who are the co-ops' main suppliers) lower than the sector average (10\% SL). The reduced profitability could be due to either reduced earnings, proportionally excessive costs, or to both of these. In this case, the ratio between some of the analyzed expenses and turnover, especially those for labour and depreciation, are higher than those in the sector, although the difference is not statistically significant. However, turnover is significantly lower than the sector average (1\% SL) and the fixed assets/turnover ratio is significantly higher, a symptom of an oversized fixed structure as compared to the sector average (5\% SL).

One of the objectives considered in a merger could be the desire to increase the members' earnings. In fact, some studies, including that of Nilsson and Madsen (2007) point out that in cross-border mergers of agricultural cooperatives, the members' main interest is the price that they get for the agricultural produce when selling it to their cooperative or to other processing firms. The members do not care about how the market value of the co-operative is affected by an eventual merger, since the shares that the members own in the co-operative are not tradable or appreciable.

- Finally, cooperatives involved in mergers in which a new enterprise is created, even though their turnovers are lower than the sector average (10\% SL), have a fixed assets/turnover ratio close to the cooperative sector average. As regards their cost efficiency ratios and profitability, there is only a lower significant difference (10\% SL) for the financial expense ratio.

\section{Research Question 1.1: Are there significant differences in the proposed indicators between the cooperative profiles analyzed: acquiring, acquired and cooperatives involved in a merger by forming a new entity?}

The results are given in Table 4, in which significant differences are identified between the three groups by the letters $a, b$ and $c$. The differences were found in the following indicators: turnover, fixed assets and quick ratio.

We therefore see that acquired cooperatives are in a much better liquidity and solvency situation than the acquiring, although statistically significant only in the case 
of liquidity (quick ratio). The cooperatives involved in a new organization are in an intermediate situation. Kenkel et al (2003) carried out a similar analysis of the financial performance prior to the merger in Oklahoma co-ops and obtained the opposite result, since they found significant differences in liquidity, the acquiring liquidity being higher than that of those acquired.

As regards business size, acquiring co-ops have turnovers significantly higher than acquired (1\% SL) and also higher than cooperatives involved in mergers by formation (10\% SL). The differences between acquired and cooperatives involved in mergers by formation are not significant. Similarly, in volume of fixed assets (the only statistically significant difference between the three types), acquiring co-ops are bigger than those involved in the creation of a new enterprise (5\% SL), which, in turn, are larger than the acquired cooperatives (5\% SL). The difference between acquired and acquiring is statistically significant (1\% SL).

\section{Research Question 1.2.: What factors in a merger determine the role (acquiring or acquired) played by a cooperative?}

Relative size could be a factor that determines whether a co-op is acquired or an acquirer in a merger. Studies exist that maintain that acquirers usually have a relative size greater than those acquired (Ravenscraft and Scherer, 1987; Bruton et al, 1994, Larsson and Finkelstein, 1999). In order to identify the determinants of the role (acquiring or acquired) played by a cooperative (among which size appears to be one of the most probable) a probit analysis was carried out in which acquiring cooperatives were assigned a value $\mathrm{y}=0$ and acquired $\mathrm{y}=1$. The model was able to correctly predict $68.24 \%$ of the cases (Table 5).

Although the initial approach was to determine the influence of size, financial situation (liquidity and solvency), profitability and cost efficiency, through appropriate ratios, the strong correlation between some of these made it impossible to integrate all of them in the same model. The cost efficiency ratios (labour cost, depreciation or supplies / turnover are essential determinants of profitability in whatever type of co-op, so that we had to opt for including in the model either a profitability or a cost efficiency indicator. Tests were carried out with both options and showed that neither of the cost efficiency indicators was significant or determinant in defining the role of a co-op in a merger (acquirer or acquired), which coincides with the results of the tests given in Table 4. We finally opted for a model that included a profitability indicator (as well as size and financial stability), as profitability is influenced to some extent by cost 
efficiency, so that its effect is already included in profitability. Similarly, the strong correlation between the financial indicators (solvency and liquidity) led us to choose only one of these, as when both were included one of the two generally appeared to be less significant or even completely insignificant.

The results show that when one cooperative acquires another, liquidity, business size and return on assets are the most important economic-financial factors in determining the cooperatives' role. In an acquisition merger, the probability of being acquired rises with liquidity (10\% SL) and falls with higher turnover (5\% SL). Thus, each extra unit of liquidity increases by $8.3 \%$ the probability of being acquired as against being an acquirer; for every extra $€ 1 \mathrm{~m}$ invested in fixed assets, the probability of being acquired as against being an acquirer decreases by $8.9 \%$. For each additional unit of the profitability of assets, the probability of being acquired decreases by $8.3 \%$. Return for members is not significant.

\section{Research Question 2: Do agricultural cooperative mergers result in improved efficiency, size and financial performance?}

Lastly, this analysis will determine to what extent the agricultural cooperatives that have participated in merger processes have succeeded in improving their economicfinancial position, by comparing their pre and post-merger performance. The use of this approach requires fictitious aggregate accounts for the year prior to the merger, similar to the accounts the cooperatives involved in the merger would have had if they had already been merged in the year N-1. The pre-merger ratios are based on these accounts. For this purpose the procedures followed by Healy et al. (1992), Clark and Ofek (1994), Apellániz et al.(1996) were adopted, calculating the resulting values of each cooperative for the year preceding the merger $(\mathrm{N}-1)$. This involved extrapolating the value of the different ratios of a fictitious co-op obtained by totalling the values of the merging coops in the previous year. This was done by adding the data from the original entities weighted by size and measured by the total assets of each co-op after the merger. This means that the value of the ratios of the acquired firm somehow has a repercussion on the ratios estimated for the hypothetical aggregated cooperative before the merger, since, if they are calculated from the consolidated balance, the reduced value of the acquired co-op's contribution is often very small. The postmerger/premerger ratio was calculated for each variable and year of study. Additionally, premerger and postmerger 
industry adjusted ratios were calculated ${ }^{5}$ by dividing the cooperatives' ratios by the mean sector ratios. These ratios prevent interferences from business cycle influence, and eliminate effects arising from causes unrelated to the merger (Healy et al. 1992; Clark and Ofek, 1994; Sharma and Ho, 2002; Kumar, 2009). Values above one indicate that the industry adjusted ratio have higher levels after the merger than before it, and those lower than one indicate that the industry adjusted ratio for cooperatives is lower after the merger than before it.

From Table 6 it can be concluded that there are only significant differences between pre and post-merger industry adjusted ratios at 5\% SL in fixed assets and cash flow for members and at $10 \%$, in solvency, return for members, and supplies/turnover.

\section{Evolution of business size indicators}

Mergers are responsible for size increases over and above the size of the enterprise at the time of the merger.

There was a rise in both turnover and sector-adjusted turnover in $60 \%$ of cases, although this rise is only statistically significant in the first (5\% SL). These results agree with those of Richards and Manfredo, 2003, Kenkel et al, 2003, and Sergaki and Semos, 2006, who showed that mergers achieve the objective of increasing sales.

The volume of fixed assets increases significantly after a merger (1\%), as does the sector-adjusted ratio (5\% SL). In some cases the rise in fixed assets is not necessarily due to increased business activity but to the revaluation of the assets' book value, already mentioned in the definition of the cash flow ratio for members. This rise in fixed assets could be due to two factors: firstly, to not re-structuring them at a lower value after the merger; this re-structuring should involve careful examination of all the assets of the cooperatives involved in the merger in order to differentiate those that will be needed to operate the unified organization from those that will not, a post-merger process recommended to improve efficiency (Wadsworth and Chesnick, 1995). Johnson (2001) calls the last assets redundant or non-operating assets, defined as those that are not required in the ongoing operations of a business and which can be extracted from the business without impairing its ability to generate prospective discretionary cash flows as forecast. The second factor is the book revaluation of assets that can be

\footnotetext{
${ }^{5}$ This methodology was used in studies such as Healy, 1992, Gosh, 2001, Sharma and Ho, 2002, and Kumar, 2009, the difference being that instead of calculating the ratio between the cooperatives and the mean for the sector, the difference between ratios was calculated. In this case the ratio was used, since it is easier to interpret for analysis purposes.
} 
undertaken in the merger, permitted by accounting legislation up to a maximum of the market value or selling price (Groh and Henseleit, 2009) in mergers that use the acquisition accounting method. This situation has been analyzed in studies such as Kaplan (1989) or Erickson and Wang (2000), who point out that the post-merger accounting results are affected, as the higher values assigned to assets imply higher depreciation costs (Apellániz et al, 1996).

At the present time, the International Financial Reporting Standards only recognize application of the acquisition method. In the present study we were not able to identify the real reason for the rise in fixed assets, whether it was due to revising the book value (which could even hide post-merger asset re-structuring) or by actual investment in these assets. However, there is no doubt that the rise has a negative effect on the final accounts due to the higher depreciation costs involved.

\section{Evolution of financial indicators (liquidity and solvency)}

We can see that there has been a reduction of sector-adjusted liquidity, although not statistically significant, and a reduction in sector-adjusted solvency, which occurred in $60 \%$ of cases (10\% SL). However, both pre and post-merger mean and median liquidity and solvency are significantly above the sector average (1\% SL). These results disagree with those obtained by Kenkel et al, (2003), since the post-merger debt ratio and liquidity improve slightly, although not statistically significant.

\section{Evolution of cost efficiency ratios}

One of the main objectives of firms involved in mergers is to obtain synergies through structural re-adjustments, such as reducing the costs of labour, supplies and depreciation. In the sample analysed, two of these costs evolve significantly: supplies/turnover are reduced (5\% SL) and staff costs/turnover, which rise (5\% SL). The analysis of the sector-adjusted ratios shows that supplies/turnover is the only one that changes positively.

Staff costs rise significantly post-merger $(5 \% \mathrm{SL})$, although the variation in the sector-adjusted ratio is not statistically significant and only fluctuates slightly, increasing in $48.6 \%$ of cases and decreasing in $51.4 \%$.

Financial costs and depreciation show a similar post-merger rise, although not significant, both individually (in 60 and $45 \%$ of cases, respectively). These results indicate a slight post-merger rise in expenses/turnover, leading to a loss in productivity, in agreement with the results obtained in studies such as Harmelen (2012), who analyzed mergers in the Dutch real estate sector. 
However, our findings on synergies in the different cost areas differ from those obtained by Kwan and Wilcox (2002), Kenkel et al. (2003) and Harrison (2008), who did find that mergers achieved significant cost reductions. Of these, only the Kenkel study (2003) focused on co-ops and found that mergers improved efficiency in personnel expenses and total expense ratios.

As regards supplies/turnover, the indicator of the percentage of turnover dedicated to supplies (a large part of these are obtained from members who also play the role of providers) was reduced after a merger, considering the ratio either individually or compared to the sector average. The difference between pre and post-merger industry adjusted ratios was significant, at a 5\% SL and a 10\% SL respectively. This result, at the very least, casts doubt on the benefits of mergers for the members of the cooperative, at least in their role as suppliers, as these were the only item of the analysed expenditure that was reduced after the merger, leaving the members at a clear disadvantage.

\section{Evolution of profitability}

Ketelhöhn and Martín (2009), and others, have found that pre-merger financial performance is a key factor to its success, although the inferences on the influence of pre-merger on post-merger performance are not conclusive. Servaes (1991) and Morck et al. (1990) found that previous high profits of acquiring firms made a significant contribution to a successful merger. On the other hand, Clark and Ofek (1994) and Servaes (1991) claim that firms with low pre-merger profit levels tend to achieve better results.

Our results show that the four profitability indicators analyzed, (return for members, cash flow for members, operating profit and return on assets) tend to fall when adjusted for the sector (post-merger industry adjusted ratio/premerger industry adjusted ratio is below 1), although only the first and second are statistically significant (at a $10 \%$ and $5 \%$ SL, respectively), which is observed in $73.85 \%$ of processes in the first case, and $69.23 \%$ in the second. If the same analysis is performed without corrections for sector data, besides the returns to members and cash flow for members ratios, the return on assets ratio at $5 \%$ would also be significant, with post-merger reductions in $64.62 \%$ of cases. This fall in returns to members is due to not reducing the weight of the different costs on turnover. Returns to members is the only item of expenditure that was significantly reduced.

Post-merger integration are one of the key elements in the process and have been defined by Chakrabarti and Mitchell (2004) as a process of adaptation in which the 
acquiring company and the acquired company perform a transfer of competences and work on achieving acquisition goals. This constitutes the most challenging phase during which value creation should be involved, but which may also involve numerous integration problems (Savovic, 2012). This phase of the merger is the motor of organizational change and development, and it plays the key role in an overall regeneration strategy. It includes post-acquisition reconfiguration, redeployment, labour reductions and structural redesigning with the goal of decreasing costs and redundancies (Chakrabarti and Mitchell, 2004; Elsass and Veiga, 2006). Faulty integration is a significant cause for merger failures (Shrivastava 1986, Haspeslagh and Jemison 1991, Habeck et al. 2000).

The results tend to show that in many cases an appropriate integration process was not carried out, i.e. the amalgamation of the human and material resources of both co-ops did not include a re-structuring in accordance with an optimization of resources plan to improve the profitability of the new enterprise. This has meant that in spite of a higher turnover members' earnings have declined.

\section{Conclusions}

The economic-financial analysis of the post-merger situation of cooperatives shows a low capacity to generate operational results in relation to turnover (1\% SL) as compared with the sector, although the reasons for this lower profitability vary according to the role played by the cooperative in the merger. Acquiring cooperatives have an excessive fixed assets/turnover ratio and a consequently higher depreciation costs/turnover when compared with the sector (1\% SL and $10 \% \mathrm{SL}$, respectively). In this regard, the expectations of expanding business operations to achieve more efficient use of assets is often a motive for acquiring societies to take on a merger.

In the case of acquired co-ops, besides also having a fixed assets/turnover ratio significantly higher than the sector mean $(5 \%$ SL), their level of returns for members (for both the goods supplied to the co-op and patronage refund) is significantly lower than the sector average (10\% SL). As regards the differences between the three roles analyzed, significant differences were found in the areas of size and liquidity. The acquiring cooperatives are the largest in size, followed by those involved in mergers by creation of a new company and, lastly, by the acquired cooperatives (1\% and 5\% SL, respectively). The order is the reverse if we look at quick currency, with the acquired cooperatives having the highest liquidity, followed by those involved in the creation of 
a new cooperative and lastly by the acquiring cooperatives (5\% and $10 \%$ SL, respectively).

The logit analysis carried out to identify the factors that determine the role played by a cooperative in a merger by acquisition confirms that when one cooperative acquires another, liquidity, business size and return on assets are the most important economic-financial factors in determining the cooperatives' role. The likelihood of being taken over as against being an acquirer therefore increases with liquidity (10\% SL) and, on the other hand, falls as turnover and profitability increase (5\% SL in both cases).

Two factors are considered to be key elements in achieving economies of scale in a merger: growth, or increased size (turnover), and reduction of costs (Hudson and Herndon, 2000, Russo et al. 2000 or Arcas Lario and Hernandez-Espallardo, 2013). The comparative pre and post-merger analysis shows in the former case a rise in turnover, significant when analyzed individually (5\% SL), and although not statistically significant when adjusted for the sector, in $60 \%$ of mergers. Other authors, including Richards and Manfredo (2003) and Kenkel et al. (2003) have found the same growth effect in cooperatives.

As regards reducing costs, a key factor in successful mergers, (Haspeslagh and Jemison ,1991; Hudson and Herndon, 2000; Schweiger and Very, 2003) point out that this is not achieved, since there are no significant changes in staff, financial and depreciation costs as a percentage of turnover, whether analysed individually (staff costs rise significantly $(5 \% \mathrm{SL}))$ or adjusted for the sector. The only costs that showed a statistically significant downward evolution, analysed both independently and sectoradjusted, (5\% and 10\% SL, respectively) were supply costs, which is unfavourable to members, the main suppliers. Even with this supply cost reduction, merged cooperatives were not able to increase performance. In spite of the increased earnings, mergers did not achieve one of their main objectives, i.e. increasing returns to members, which in fact were significantly reduced (in the form of return for members and cash flow for members), both individually (1\% SL in both) and sector adjusted (10\% and 5\% SL, respectively). Both ratios were reduced in $70 \%$ and $73.8 \%$ of mergers, respectively. Other studies have found similar results and did not find evidence of improved profits in capital societies (Ghosh, 2001; Sharma and Ho, 2002; Colarte and Rodriguez, 2006; Kumar, 2006), or have even found that profitability declines and efficiency drops 
(Ravenscraft and Scherrer, 1987). Neither could Parliament and Taitt (1989) prove any post-merger performance improvement in cooperatives.

This element should give pause for reflection, since cooperatives exist to provide a service to their members, who are their main assets. This should be borne in mind by governments who promote and encourage mergers with the guarantee of improving profits through economies of scale. Mergers per se do not guarantee improvements in the management indicators of the cooperatives involved in mergers, especially those that directly affect the members.

The results indicate that in many cases mergers do not result in real post-merger integration and that the amalgamation of the human and material resources of both participants is not always accompanied by the spending cuts necessary to reduce costs. This, together with a higher turnover (which does in fact happen) would bring about economies of scale and increased profits. The post-acquisition integration plays a key role in an overall regeneration strategy, and includes post-acquisition reconfiguration, redeployment, staff cuts and structural redesigning with the goal of decreasing costs and redundancies (Chakrabarti and Mitchell, 2004; Elsass and Veiga, 2006).

The serious situation of the small agrifood co-ops in Spain makes it necessary to carry out an integration and re-structuring process (Juliá et. al., 2008, Juliá et. al 2011; Baamonde, 2012). However, as Giagnocavo and Vargas-Vasserot (2012) have pointed out, the most appropriate methods must be researched so as to understand what functions in a complex legal, historical, social and cultural context, since the integration strategies that have been successful in other countries cannot automatically be applied to Spain. Although all the different methods of achieving growth must be tried, the most important consideration, whatever formula is applied, is to achieve a balanced growth that answers the operational needs of the cooperatives while at the same time protecting the interests of their members.

Although mergers may be seen as one of the most appropriate formulas, given the extremely delicate situation of most of the Spanish agrifood cooperatives (72\% of which have turnovers below $€ 5 \mathrm{~m})$, they will only be effective when real integration is ensured and not simply a joining together of the resources of both participants. Without this type of measure, mergers may be fruitless, or might even worsen the economicfinancial indicators, especially the returns for members, and members are the key figures and raison d'etre of cooperatives, as has been shown by the results of this study. 


\section{Limitations and contributions of the study}

Many different factors play a role in the deficient financial performance of food cooperatives (e.g. weak management or underdeveloped marketing management, or the absence of competitive market strategies such as product differentiation, market segmentation, specialization, and diversification) and prevent increases in profit margins and expansions in demand (Pashkova et at, 2009). Although these factors were not taken into consideration in the present study, they undoubtedly have an influence on negative post-merger performance.

It should also be pointed out that we were not able to determine the real cause of the increase in the value of fixed assets (responsible for the rise in depreciation costs) or whether it is due to the updating of their book value, investments in new assets, or both, as this information is not available in the annual accounts used as the data source for the study.

We must also point out that the post-merger analysis was limited to four years. Although certain indicators were seen to evolve negatively in this period, including members' returns (statistically significant), this situation could have been corrected in subsequent years in some cases.

Finally, we would like to point out that our main contribution has been to compile an empirical study on the results of mergers carried out between Spanish agrifood cooperatives, with special emphasis on the effects on their members' earnings. Such studies are in great demand in a number of areas (government administrations, cooperative associations, etc.) due to the large numbers of small co-ops in existence and the lack of similar studies in this field. The fact that there is a significant reduction in members' earnings (the main participants in co-ops) should at least make co-ops think twice before considering a merger, in order to define an integration process that corrects this situation and guarantees its viability.

\section{References}

APELLANIZ P., SERRANO C., APELLANIZ T., 1996, Evaluación de los resultados de las fusiones a partir de la información contable, Revista Española de Financiación y Contabilidad XXV, Vol. 87, 429-457.

ARCAS LARIO N., HERNÁNDEZ ESPALLARDO M., 2013, Tamaño y competitividad, Casos destacados de cooperativas agroalimentarias españolas, Mediterráneo Económico 24, ISSN: 1698-3726-ISBN-13: 978-84-95531-59-9, 205-230. 
BAAMONDE E., 2012, Plan estratégico del cooperativismo agroalimentario Español, Tendencias en la Unión Europea, Confederación de Cooperativas Agrarias de España.

BAOURAKIS G., DOUMPOS M., KALOGERAS N., ZOPOUNIDIS C., 2002, Multicriteria Analysis and Assessment of Financial Viability of Agribusinesses: The Case of Marketing Cooperatives and Juice-Producing Companies. Agribusiness, 18(4): 543-58.

BIJMAN J. et al, 2012, Support for farmer's cooperatives. Final Report.

BRICKLEY J., JARRELL G., NETTER J., 1988, The Market for Corporate Control: The Empirical Evidence since 1980, Journal of Economic Perspectives, Vol. 49.

BRUTON G. D., OVIATT B. M., WHITE M. A., 1994, Performance of acquisitions of distressed firms, Academy of Management Journal, 37: 972-989.

CHAKRABARTI A., MITCHELL W., 2004, A Corporate Level Perspective on Acquisitions and Integration, Retrieved February, 15, 2011.

CHATTERJEE R., MEEKS G., 1996, The financial effects of takeover: Accounting rates of return and accounting regulation, Journal of Business Finance and Accounting, vol. 23, 851-868.

CLARK K., OFEK YE., 1994, Mergers as a means of restructuring distressed firms: An empirical investigation, J Financial Quant Anal, Vol. December, 541-561.

COLARTE T., RODRÍGUEZ J., 2006, Resultados económicos y financieros de las fusiones en España: Un análisis empírico con información contable, Revista Española de Financiación y Contabilidad XXXV, Vol. 129 abril-junio, 275-303.

COMISIÓN DE AGRICULTURA Y DESARROLLO RURAL, Parlamento Europeo, 2009, Informe sobre los Precios de los Productos Alimenticios de 24 de febrero de 2009, presentado al Parlamento Europeo.

CUERVO A., 1999, Razones para las fusiones y adquisiciones: factores organizativos no explícitos como determinantes del éxito, Economistas, № 82, 20-31.

ELSASS M. P., VEIGA, F. J., 1994, Acculturation in Acquired Organizations: A Force-fi eld Perspective, Human Relations, In Risberg, A., 2006, Mergers and Acquisitions A Critical Reader, Routledge Taylor and Francis Group.

ERICKSON M., WANG S., 2000, The Effect of Transaction Structure on Price: Evidence from Subsidiary Sales, Journal of Accounting and Economics, Vol. 30, 59-97. 
FRANK J., HARRIS R., TIMAN S., 1991, The post merger share-price performance of acquisitions, Journal of Finance 44: 41-57.

GHOSH A., 2001, Does operating performance really improve following corporate acquisitions? Journal of Corporate Finance, Volume 7, Number 2, June 2001, 151-178 (28).

GIAGNOCAVO C., VARGAS-VASSEROT C., 2012, Support for Farmers' Cooperatives; Country Report Spain, Wageningen: Wageningen UR.

GROH A. P., HENSELEIT C., 2009, The valuation of tax shields induced by asset step-ups in corporate acquisitions, Working Paper, WP-785, March, 2009.

GUZMÁN I., ARCAS N., GARCÍA D., 2006, La eficiencia técnica como medida de rendimiento de las cooperativas agrarias CIRIEC-España, Revista de Economía Pública, Social y Cooperativa 55: 289-311.

HABECK M., KRÖGER F., TRÄM, M., 2000, After the merger-seven rules for successful post-merger inte-gration Pearson Education Limited: Edinburgh Gate, GB.

HANAN M.T., FREEMAN J., 1984, Structural Inertia and Organisational Change American Sociology Review, 49(2): 149-164

HALPERN P., 1983, Corporate acquisitions: A theory of special cases? A review of event study cases applied to acquisitions, Journal of Finance 2: 297-318.

HARDESTY S.D., SALGIA V.D., 2004, Comparative Financial Performance of Agricultural Cooperatives and Investor-Owned Firms, Paper Presented At NCR-194 Research on Cooperatives Annual Meeting November 2-3, 2004 Kansas City, Missouri.

HARMELEN D., 2012, Efficiency Effects: The Effects of a Horizontal Merger on Cost-Efficiency, Bachelor Thesis, University Rotterdam.

HARRISON D.T., 2011, Do Mergers Really Reduce Costs? Evidence from Hospitals. Economic Inquiry, Volume 49, Issue 4, 1054-1069, October 2011.

HASPESLAGH P., JEMISON D., 1991, Managing Acquisitions-Creating Value Through Corporate Re-newal The Free Press: New York, USA

HEALY P.M., PALEPU K.G., RUBACK R.S., 1992., Does corporate performance improve after mergers?, J Financial Econ, Vol. 31, 135-175.

HUDSON D., HERNDON C.W., 2000., Mergers, Acquisitions, Joint Ventures and Strategic Alliances in Agricultural Cooperatives, Department of Agricultural Economics, Research Report 2000-2009, Mississipi State University. 
JAMES H.S., SYKUTA M.E., 2005, Property right and organizational characteristics of producerowned firms and organizational trust, Annals of Public and Cooperative Economics, 76:4, 545-580.

JENSEN M.C., RUBACK R.S., 1986, Market for Corporate Control, AEA Papers and Proceedings, Vol, 76. No.2.

JONSHON H.E., 2001, Financial Statement Analysis in Mergers and Acquisitions.

JULIÁ J.F., MELIÁ E., 2008, Social Economy and the cooperative movement in Europe: contributions to a new vision of agriculture and rural development in the Europe of the 27, Ciriec-España, Revista de Economía Pública, Social y Cooperativa, Vol 68, 141-168.

JULIÁ J.F., MELIÁ E.,GARCÍA MARTINEZ G., 2011, Strategies developed by leading EU agrifood cooperatives in their growth models. Service Business. Vol. 5.

KAPLAN S., 1989, Management Buyouts: Evidence on Taxes as a Source of Value. The Journal of Finance, Vol. 44, No.3, 611-632.

KENKEL F., GILBERT A., SPENCE B., 2003, Post Merger Financial Performance of Oklahoma Cooperatives, Selected Paper for presentation at the SAEA Annual Meetings, Mobile Alabama, Feb. 1-5.

KUMAR R., 2009, Post-merger corporate performance: an Indian perspective, Manage Res News Vol. 32(2), 145-157.

KUMAR TIWARI B., 2014,. A case study of merger of Benaras State Bank Ltd. (BSB) with bank of Baroda (BOB). Asian Journal of Management Sciences \& Education. ISSN: 2186-845X ISSN: 2186-8441.Vol. 3 No. 1, January 2014.

KYRIAKOPOULOS K., MEULENBERG M., NILSSON J., 2004, The impact of cooperative structure and firm culture on market orientation and performance, Agribusiness, 20 (4), 379-396.

LARSSON R. FINKELSTEIN S., 1999, Integrating strategic, organizational, and human resource perspectives on mergers and acquisitions: a case survey of synergy realization, Organization Science, Vol. 10 No. 1, 1-26.

LAGO S., VAQUERO A., 2009, Fusiones de Cajas de Ahorro: ¿Qué Sabemos? Servicio de Estudios Cajasol. (Sevilla).

LANGETIEG T., 1978, An application of three-factor performance index to measure stockholder gains from mergers, J Financial Econ, Vol. December, 365-383.

LERMAN Z., PARLIAMENT C., 1990, Comparative performance of cooperatives and investor-owned firms in US food industries, Agribusiness, 6: 527-540. 
LIMMACK R.J., 1991, Corporate mergers and shareholder wealth effects: 19771986, Accounting and Business Research, Vol. Summer, 239-251.

MALHOTRA N., 2004, Investigación de Mercados. Pearson Educación, 713 pp.

MANSON S., POWELL R., STARK A. W., THOMAS H. M., 2000, Identifying the Sources of Gains from Takeovers, Accounting Forum, 24, 319.

MARTYNOVA M., RENNEBOOG L., 2006, ECGI - Finance Working Paper No. 114/2006; Center Discussion Paper Series No. 2006-06

MCKEE G., 2008, The Financial Performance of North Dakota Grain Marketing and Farm Supply Cooperatives. Journal of Cooperatives, 21:15-34.

MELIÁ E., JULIÁ J.F., MARTINEZ-GARCÍA A., 2010, Mergers of agrifood cooperatives and their effects: from expectations to results. An empirical study in four Spanish Autonomous Regions, Spanish Journal of Agricultural Research, Vol. 8 (2), (2010) 235-250.

MELIÁ E, MARTÍNEZ-GARCÍA A., 2014, Caracterización y análisis del impacto y los resultados de las fusiones de cooperativas en el sector agroalimentario español. Editorial: Universidad de Almería, 57 pp.

MICHELSEN J., 1994, The rationales of cooperative organizations, Annals of Public and Cooperative Economics, 65:1, 13-34.

MOYANO J., FIDALGO F.A., 2001, El impacto de la dimensión en la sociedad cooperativa agraria, Una aplicacion al cooperativismo oleícola REVESCO, Revista de Estudios Cooperativos, núm. 73, 2001, 95-122.

MUELLER D.C., 1969, A Theory of Conglomerate Mergers, Quarterly Journal of Economics 83, 643-59.

NILSSON J., MADSEN O., 2007, Issues in cross-border mergers between agricultural co-operatives, Journal of Co-operative Studies, 40(3), 27-38.

OSCAE, 2013, Macromagnitudes del Cooperativismo agroalimentario español, Observatorio socioeconómico del cooperativismo agrario español.

OWEN G., PITTMAN B., MARTELL L., 2011, What do we know about nonprofit mergers? Joint research project of MAP for Nonprofits and Wilder Research. Wilder Research.

PARLIAMENT C., TAITT J., 1989, Mergers, consolidations acquisitions: effect on performance of agricultural cooperatives, Staff paper 89-37, Research supported by the Agricultural Cooperative Service of the United States Deparment of Agriculture, University of Minesota. 
PARLIAMENT C., LERMAN Z., FULTON J., 1990, Performance of Cooperatives and Investor-Owned Firms in the Dairy Industry, Journal of Rural Cooperation, Vol 5.

PASHKOVA N., NIKLIS D., ALEXAKIS D., PAPANDREOU A., 2009, Food marketing cooperatives of Crete: A financial assessment within the EU context, Paper prepared for presentation at the 113th EAAE Seminar "A resilient European food industry and food chain in a challenging world", Chania, Crete, Greece, September 3 6, 2009.

PRATT G., 1998, The need performance measurement in cooperatives: a practitioners view, The World of Co-operative Enterprise, Scottish Agricultural Organisation Society, UK, 1-8.

RAHMAN R. A., LIMMACK R.J., 2004, Corporate Acquisitions and the Operating Performance of Malaysian Companies, Journal of Business Finance and Accounting, 31 (3-4), (April-May), 359-400.

RAVENSCRAFT D., SCHERER F.M., 1987, Life after Takeovers, Journal of Industrial Economics, 36 (2), 147-56.

RICHARDS T., MANFREDO M.R., 2003 (a), Cooperative mergers and acquisitions: the role of capital constraints, J Agr Resour Econ, Vol. 28(1), 152-168.

RICHARDS T, MANFREDO M.R., 2003 (b), Post-merger performance of agricultural cooperatives, Agricultural Finance Review, Vol. 63 Iss: 2, 175 - 192.

RUSSO C., WATHERSPOON D, PETERSON C., SABBATINI M., 2000, Effects of Managers' Power on Capital Structure: a Study of Italian Agricultural Cooperatives, International Food and Agribusiness Management Review 3: 27-29.

SALTER M.S., WEINHOLD W.A, 1979, Diversification via acquisition: Creating value. Harvard Business Review, 56 (4), 166-176

SARASA C., POLO-GARRIDO F., SEGUÍ-MÁS E., 2013, Valoración de la actuación empresarial mediante técnicas multicriterio: Un análisis aplicado a cooperativas agroalimentarias valencianas, CIRIEC-España, Revista de Economía Pública, Social y Cooperativa 77: 131-153.

SAVOVIC S., 2012, The importance of post-acquisition integration for value creation and success of mergers and acquisitions economic horizons, September December 2012, volume 14, number 3, 195-207.

SCHWEIGER D., VERY P., 2003, Creating value through merger and acquisition integration, Advances in Mergers and Acquisitions, Volume 2, 1-26. Published by Elsevier Science Ltd. ISBN: 0-7623-1003-0. 
SERGAKI P., SEMOS A., 2006, The Greek Unions of Agricultural Cooperatives as efficient enterprises. Agricultural Economics Review 01/2006; 07(2).

SERRA V., GOMEZ M.A., LANDETE M., 2001, Resultados de las fusiones empresariales: Una aproximación empírica en el sector asegurador, Revista Española de Financiación y Contabilidad XXX (110), 1001-1036.

SETH A., 1990, Value creation in aquisitions: a reexamination of performance issues, Strategic Managemerzt Journal, 11, 90-115.

SHARMA D.S., HO J., 2002, The impact of acquisitions on operating performance: Some Australian evidence. Journal of Business Finance and Accounting, 29(1) and (2), $155-200$.

SHRIVASTAVA P., 1986, Postmerger integration. The Journal of Business Strategy Vol. 7, No. 1, 65-76

KWAN S. H., WILCOX J. A., 2002, Hidden cost reductions in bank mergers: Accounting for more productive banks, in (ed.) 19 (Research in Finance, Volume 19), Emerald Group Publishing Limited, 109-124.

SINGH S., COELlI T., FLEMING E., 2001, Performance of dairy plants in the cooperative and private sectors in India, Annals of Public and Cooperative Economics, 72, 453-479.

SOBOH R., OUDE LANSINK A., GIESEN A., VAN DIJK G., 2009, Performance measurement of the agricultural marketing cooperative: The gap between theory and practice, Review of Agricultural Economics, 31, 446-469.

SOBOH R., OUDE LANSINK A. VAN DIJK G., 2011, Distinguishing dairy cooperatives from investor-owned firms in Europe using financial indicators, Agribusiness: An international Journal, Vol. 1, 34-46.

VANDEBURG J., FULTON J. R., HINE S., MCNAMARA K., 2000, Driving forces and success factors for mergers, acquisitions, joint ventures, and strategic alliances among local cooperatives, Paper presented at NCR 194 Annual Meeting, Las Vegas, NV.

VAN DIJK G., KLEP L., 2005, Als 'de market' faalt (Inleiding tot cooperatie) Den Haag: Sdu Uitgevers bv.

WADSWORTH J, CHESNICK D., 1995, Consolidation of Balance Sheet Components During Cooperative Mergers, Research Report 139, 32 pp, USDA Rural Development. 
WALSH J.P., SEWARD J.K., 1990, On the efficiency of internal and external corporate control mechanisms. Academy of Management Review, 15 (3), 421-458. 